\title{
A LETRA IMOBILIÁRIA GARANTIDA E O DIREITO CONSTITUCIONAL À MORADIA
}

\section{GUARANTEED REAL ESTATE LETTER AND CONSTITUTIONAL LAW TO HOUSING}

\section{GUILHERME CARTA RIBEIRO}

Mestrando do Curso de Direito pelo Centro Universitário Curitiba - UNICURITIBA. Curitiba - PR. email:guilherme.carta@hotmail.com

\section{AKIHITO ALLAN HIRATA}

Mestrando do Curso de Direito - Centro Universitário Curitiba - UNICURITIBA. Curitiba - PR. email: akihitoadv@hotmail.com

\section{RESUMO}

O intuito deste trabalho é o estudo sobre a Letra Imobiliária Garantida e o direito a moradia. Regularmente utilizada na Europa com a denominação de "covered bond", a letra imobiliária garantida, ou LIG, é um instituto novo e pouco explorado pela doutrina pátria. A LIG foi criada pela medida provisória n. 656 de 2014 e foi posteriormente convertida na lei 13.097 de 2015. Porém, somente em setembro de 2018 que o Banco Central do Brasil concluiu sua regulamentação do ponto de vista operacional. A LIG tem como características ser título de crédito nominativo, transferível e de livre negociação. Pode ser composta por créditos imobiliários, títulos de emissão do Tesouro Nacional, instrumentos derivativos e outros ativos que venham a ser autorizados pelo Conselho Monetário Nacional. A Carteira de Ativos deve atender a requisitos de elegibilidade, composição, suficiência, prazo e liquidez estabelecidos pelo Conselho Monetário Nacional bem como que esses ativos não 


\section{Personalidade Acadêmica Homenageada:}

Carlos Aurélio Mota de Souza (Universidade Ibirapuera - UNIB)

podem estar sujeitos a qualquer ônus. Em relação ao crédito imobiliário, os ativos somente poderão integrar a carteira no caso de serem garantidos por hipoteca, por alienação fiduciária de coisa imóvel ou no caso da incorporação imobiliária objeto da operação de crédito estiver submetida ao regime de afetação. A LIG é considerada como titulo executivo extrajudicial podendo ser executada com base em certidão de inteiro teor emitida pelo depositário central. A finalidade da LIG é ser uma nova fonte de recursos, fomentando o mercado imobiliário e garantindo o direito constitucional à moradia. A principal vantagem para adotar a LIG é sua segurança, especialmente para o investidor, vez que apresenta uma quádrupla garantia. As garantias podem ser assim enumeradas: o próprio imóvel; a instituição emissora visto que responde pelo adimplemento de todas as obrigações decorrentes da LIG, independentemente da suficiência da carteira de ativos; ser garantida pelo fundo garantidor de crédito ${ }^{1}$, ressalvadas suas condições e a garantia acessória da instituição emissora do crédito. Ainda, o investidor pessoa física, tanto o residente quanto o não-residente, conta com um importante incentivo na LIG, uma vez que é isento de imposto de renda. Tendo em vista a recente regulamentação, ainda não há aplicação prática da LIG, sendo esperada a primeira emissão para primeiro semestre de 2019. Por fim, concluímos que a LIG tem capacidade de influenciar de forma positiva o mercado imobiliário por ser um novo funding de recursos. Ao investidor, será uma interessante forma de investimento por contar com várias garantias, não sendo igualável a outra forma de garantia de investimentos. Ainda, conta com a isenção do imposto de renda o que poderá atrair ainda mais recursos. Porém, tendo em vista as excessivas garantias, e tendo em mente que o retorno dos investimentos é proporcional ao risco, espera-se que a rentabilidade seja menor comparado com outras formas de investimento. Em relação ao direito a moradia, assim como ocorreu com a lei de alienação fiduciária, será uma importante fonte de recursos, capaz de garantir o direito constitucional à moradia. Pode ser definida assim: "O direito à moradia é evidenciado pela habitação de dimensão adequada, em condições de

\footnotetext{
${ }^{1}$ É necessário mencionar, que tal garantia não está pacificada na doutrina.
} 


\section{Personalidade Acadêmica Homenageada:}

Carlos Aurélio Mota de Souza (Universidade Ibirapuera - UNIB)

higiene e conforto, que promova o bem-estar de seus ocupantes ${ }^{2}$." É necessário perceber que este direito é tão importante que o art.6 da CF, fundamenta a impenhorabilidade do bem de família. "Parece-nos, também, que a Lei 8.009/90, que dispõe sobre a impenhorabilidade do bem de família, encontra fundamento no art.6 da CF/883." Não devemos deixar de mencionar o art. 23,IX da CF/88, o qual dispõe da competência dos entes da federação para promoção de programas de construção de moradias e de melhorias das condições de habitação. ${ }^{4}$ Desta forma, o tema tratado se bem desenvolvido, poderá ser uma alavanca para o direito de moradia. A metodologia utilizada é a revisão bibliográfica e analise de jurisprudências.

PALAVRAS-CHAVE: Letra Imobiliária Garantida; Lei 13.097/2015; Título Executivo Extrajudicial; Moradia.

\section{REFERÊNCIAS}

FERNANDES, Bernardo Gonçalves, Curso de Direito Constitucional. 2.ed. Rio de Janeiro: Lumem Juris editora, 2010.

LENZA, Pedro, Direito Constitucional Esquematizado, 21.ed. São Paulo: editora Saraiva, 2017.

MAMEDE, Gladston. Direito Empresarial Brasileiro: Títulos de Crédito. 5ª Ed. São Paulo: Brasil, 2013

MIRANDA, Maria Bernadete. Curso Teórico e Prático dos Títulos de Crédito. Rio de Janeiro: Forense, 2006.

\footnotetext{
2 AINA, Eliane Maria Barreiros, Direito à Moradia. 2.ed. Rio de Janeiro: Lumen Juris editora, 2004,p.88.Apud PEÑA DE MORAES, Guilherme, Curso de Direito Constitucional. 2.ed. Rio de Janeiro: editora Impetus, 2008, p.536.

${ }^{3}$ LENZA, Pedro, Direito Constitucional Esquematizado, 21.ed. São Paulo: editora Saraiva, 2017, p. 1252.

${ }^{4}$ FERNANDES, Bernardo Gonçalves, Curso de Direito Constitucional. 2.ed. Rio de Janeiro: Lumem Juris editora, 2010,p. 455.
} 
Personalidade Acadêmica Homenageada:

Carlos Aurélio Mota de Souza (Universidade Ibirapuera - UNIB)

NEGRÃO, Ricardo. Manual de Direito Comercial e de Empresa. São Paulo: Saraiva, 2009.

PEÑA DE MORAES, Guilherme, Curso de Direito Constitucional. 2.ed. Rio de Janeiro, editora Impetus, 2008.

TOMAZETTE, Marlon. Curso de Direito Empresarial: Títulos de Crédito. 2 Ed. São Paulo: Atlas, 2009. 